\title{
RECORDS OF AMERICAN MILLIPEDS AND CENTIPEDS COLLECTED BY DR. D. ELDEN BECK IN 1950
}

\author{
RALPH V. CHAMBERLIN \\ Emiritus Professor of Biology \\ University of Utah \\ Salt Lake City, Utah
}

In the course of field work carried out in various parts of the United States in 1950, Dr. D. Elden Beck, Brigham Young University, Provo, Utah, incidentally collected the millipeds and centipeds listed in the present paper. Included in the list, however, are a few forms taken during earlier years. The collection is of interest not only in embracing representatives of the four new species herein diagnosed, but also in adding important distributional data on previously known forms.

\section{DIPLOPODA \\ Order POLYDESMIDA}

Family Polydesmidae

POLYDESMUS COMPLANATUS Linne

New Jersey: Nutley, May 7, 1950, males and females.

A species introduced from Europe.

\section{PSEUDOPOLYDESMUS SERRATUS (Say)}

Maryland: Bethesda, November 4, 1949, two specimens; Vermont: Barre, June 10, 1950, one female.

DIXIDESMUS PHANUS Chamberlin, new species

A species most closely related to $D$. conlatus (Chamberlin) and D. sylvicolens Chamberlin. In size, it is much smaller than the former, its length being $18 \mathrm{~mm}$. as against $22 \mathrm{~mm}$. or more, and somewhat larger than the latter.

From both those species the present one differs in the details of the gonopods of the male, e.g. in having a terminal tooth set at right angles to the axis, in the arrangement of the teeth and setae on the terminal division, in the larger ectal process which extends farther caudad and overlaps the axillary spine, and in having the tooth on the mesal edge proximad of the level of the cushion abortive. The axillary seta or spine is characteristically geniculate near its base and arises much closer to the cushion than in the other species. See further Fig. 1. 

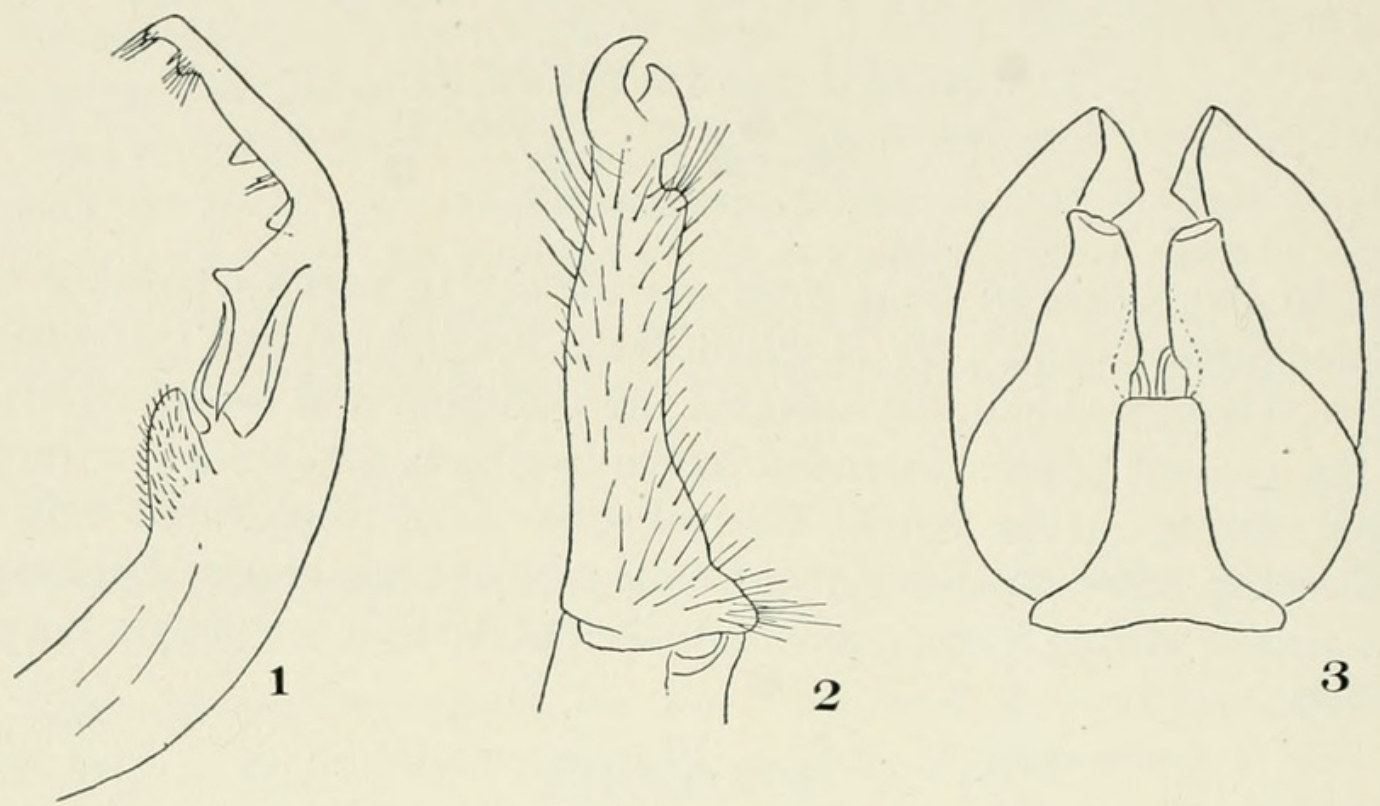

3

Fig. 1. Dixidesmus phanus, n. sp. Left gonopod of male, ectal aspect. Fig. 2. Auturus becki, n. sp. Right gonopod of male, caudal aspect. Fig. 3. Nannolene corticolens, n. sp. Gonopods of male, anterior aspect.

Locality: Florida, Suwannee River. Five specimens were taken on April 15, 1950. Type and paratypes in writer's collection, University of Utah.

Family Xystodesmidae

APHELORIA CORIACEA (Koch)

New York: Ithaca, June 13, 1950, male and female.

EPELORIA LEIACANTHA Chamberlin

Georgia: Ft. Benning, one male, which is larger in size than the types, taken April 16, 1950.

HARPAPHE sp.

California: Muir Woods National Monument, one female of uncertain species, August 10, 1950.

\section{ZINARIA CALA Chamberlin}

Florida: Suwannee River, one male, April 15, 1950.

Family Eurydesmidae

SEMIONELLUS PLACIDUS (Wood)

Georgia: Ft. Benning, four specimens, April 16, 1950. 


\section{Family Stiodesmidae}

\section{PSOCHODESMUS CRESCENTIS Cook}

Florida: Archbold Biological Station at Lake Placid; several specimens, April 7, 1950.

\section{Family Strongylosomidae \\ OXIDUS GRACILIS (C. Koch.)}

North Carolina: Greensboro, several specimens, April 22, 1950.

An Asiatic species introduced and now widely established, especially familiar in greenhouses.

Family Euryuridae

AUTURUS BECKI Chamberlin, new species

Dorsum dark brown, with the usual median light spot on caudal border of each tergite, this spot very large and probably orange or yellow in life but now bleached out; a similar light spot on and adjacent to each keel. Legs yellow.

Last dorsal plate with sides parallel over middle part of length, and caudad of this a little converging to the rounded posterior corners; caudal margin slightly indented at middle.

The gonopods of male nearest in form to those of $A$. georgianus Chamberlin, but more robust; the outer distal lobe relatively more elongate, and more curved and pointed at the end instead of being widely rounded. See further, Fig. 2.

Length, $23 \mathrm{~mm}$; width, $2.8 \mathrm{~mm}$.

Locality: Florida, Suwannee River, five specimens, April 15, 1950. Type and paratypes in writer's collection, University of Utah.

\section{Order JULIDA}

Family Julidae

\section{DIPLOIULUS HORTENSIS (Wood)}

Vermont: Quechee (near Randolph), one specimen, June 9, 1950.

A species well established in the Eastern States but probably originally introduced from Europe where, in recent years, it has been most commonly known as Cylindroiulus frisius Verhoeff. 


\section{DIPLOIULUS CAERULEOCINCTUS (Wood)}

New Jersey: Nutley, several, May 7, 1950; Vermont: Quechee, one female, June 9, 1950.

This species, abundant in the east, is an essentially synanthropic form which occurs commonly also in England and other parts of western Europe.

\section{OPHYIULUS PILOSUS (Newport)}

Virginia: Charlottesville, several specimens, April 26, 1950; Vermont: Quechee (near Randolph), one specimen, June 9, 1950.

\section{Family Nemasomidae \\ NOPOIULUS MINUTUS (Brandt)}

Utah: Salem, several specimens, April 15, 1949. Provo, one specimen, October 18, 1950.

A synanthropic species introduced from Europe.

Family Paraiulidae

TAIULUS TIGANUS (Chamberlin)

Utah: Springville, several, collected by V. J. Tipton, April 6, 1949, Canyon Glen at Provo Canyon, several specimens taken by D. Elden Beck, May 22, 1947.

\section{Order LYSIOPETALIDA \\ Family Callipodidae \\ SPIROSTREPHON LACTARIUM (Say)}

New York: Ithaca, one, June 19, 1940.

In addition immature specimens of this or a related form were taken at Lake Placid, Florida.

\section{Order SPIROBOLIDA}

Family Spirobolidae

\section{SPIROBOLUS SPINIGERUS Wood}

Florida: Archbold Biological Station at Lake Placid, several specimens, March 16, 1950, at Ocala, one female, April 13, 1950. 


\section{Order CAMBALIDA \\ Family Cambalidae}

NANNOLENE CORTICOLENS Chamberlin, new species

Body conspicuously annulate, rings of dark brown to nearly black alternating with pale rings; last tergite dark brown with caudal border pale, this border variable in width. In specimens in full color the seriate dark spots along the sides are small or obscure, but these spots show distinctly in paler individuals. Legs and antennae yellow. The head pale across vertex, the color solid; a dark line between inner angles of eyes and the area below this a lighter dusky color down to the pale clypeus, the dusky area enclosing below level of antennae two darker, usually elongate spots above and below which are paler areas. Body entirely lacking the violaceous pigment giving name to N. violacea.

Ocelli mostly 18 to 20 in number.

Body having the usual beaded or moniliform appearance; moderately constricted behind collum in the female, more strongly so in the male. Last tergite long.

Appearing distinct from previously described forms in the details of the male gonopods; e.g., in the proportions of the anterior sternite, the form of the distal ends of the anterior coxae which widen proximad more gradually than in violacea and have their distal ends more decidedly truncate. For these and other details see Fig. 3.

Number of segments, mostly 54-55.

Length, up to $20 \mathrm{~mm}$.

Locality: California, Marsh Creek Springs (near Concord) at north base of Mt. Diablo, several specimens of both sexes, August 14, 1950. Type and paratypes in writer's collection, University of Utah.

\section{CHILOPODA}

\section{Order LITHOBIIDA}

\section{Family Lithobinde}

\section{LITHOBIUS FORFICATUS (Linne)}

Nevada: McGill, one male and two females, August 5, 1950; Nebraska: North Platte, two males, June 22, 1950; Vermont: Quechee (near Randolph), two males, June 9, 1950, Rutland, one male and two females, June 10, 1950, Barre, two males and one female, June 10, 1950; New York: Albany, a male and female, June 11, 1950; 
New Jersey: Nutley, two males, May 7, 1950; Maryland: Bethesda, a male and female, November 4, 1949.

\section{LITHOBIUS ATKINSONI Bollman}

Georgia: Ft. Benning, a female, April 16, 1950.

\section{NEOLITHOBIUS ETHOPUS Chamberlin}

Florida: Gainsville, a male and female, April 14, 1950, Archbold Biological Station at Lake Placid, one male, April 7, 1950, Suwannee River (near Oldtown), two females, April 15, 1950.

\section{NEOLITHOBIUS MORDAX (L. Koch)}

Nebraska: Omaha, a male and female, June 20, 1950.

NEOLITHOBIUS TRANSMARINUS (L. Koch)

Louisiana: Camp Plauche (near New Orleans), four males and one female, January 24, 1944.

\section{NEOLITHOBIUS UNDERWOODI (Bollman)}

Georgia: Ft. Benning, a male and female, October 24, 1943.

\section{NEOLITHOBIUS VORAX (Meinert)}

Florida: Archbold Biological Station at Lake Placid, one female, March 11, 1950.

\section{NEOLITHOBIUS XENOPUS (Bollman)}

Georgia: Ft. Benning, one female, November 12, 1943.

This species, originally described in 1888 from a single male taken at Macon, Georgia, has not been since recorded until now. In addition to the specimen taken by Dr. Beck, there were found, in the course of the present study, nine additional specimens in the University of Utah collection that were taken at Gainsville, Florida in 1942 (Ivie, collector).

\section{GARIBIUS GEORGIAE Chamberlin}

Georgia: Ft. Benning, one female, November 20, 1943.

\section{PAOBIUS VAGRANS Chamberlin}

Vermont: Quechee (near Randolph), one female, June 9, 1950.

TAIYUBIUS HARRIETAE Chamberlin

Nevada: McGill, one male, August 5, 1940.

Previously known from Colorado. 
Family Gosibirdae

GOSIBIUS SACCHAROGEUS Chamberlin

Louisiana: Camp Plauche (near New Orleans), a male and female, January 24, 1944.

Previously known only from Texas.

\section{Order SCOLOPENDRIDA \\ Family Cryptopidae \\ CRYPTOPS HYALINUS (Say)}

Georgia: Ft. Benning, two imperfect specimens, November 20, 1943.

\section{OTOCRYPTOPS SEXSPINOSUS (Say)}

New York: Ithaca, one specimen, June 13, 1950; North Carolina: Greensboro, several partly grown, April 22, 1950; Florida: Gainsville, two specimens, April 14, 1950; Archbold Biological Station at Lake Placid, two adults and one female with many young, March 5, 1950; California: Yosemite National Park, two specimens, August 17, 18, 1950; Muir Woods National Monument, several, August 10, 1950.

\section{THEATOPS POSTICUS (Say)}

Florida: Archbold Biological Station at Lake Placid, eight specimens taken April 7 and March 5-7, 1950; Gainsville, one, April 14, 1950.

Family Scolopendridae

SCOLOPENDRA VIRIDIS Say

Florida: Archbold Biological Station at Lake Placid, one, March 7, 1950.

SCOLOPENDRA POLYMORPHA WoOd

Utah: Arches National Monument, two variant specimens, May 12, 1949.

\section{SCOLOPENDRA PACHYGNATHA Pocock}

Florida: Archbold Biological Station at Lake Placid, two, March 11, 1950.

Previously known only from Mexico (Zacatecas) 


\title{
Odrer GEOPHILIDA
}

Family Chilenophilidae

\section{ARCTOGEOPHILUS XENOPORUS (Chamberlin)}

California: Yosemite National Park, one specimen, probably this species, taken August 17, 1950.

\section{ARCTOGEOPHILUS UMBRATICUS (McNeill)}

North Carolina: Greensboro, one specimen, April 22, 1950.

\author{
PACHYMERIUM FERRUGINEUM (C. L. Koch)
}

Nebraska: Omaha, two specimens, June 20, 1950.

\section{Family Geophilidae}

\section{ARENOPHILUS BIPUNCTICEPS (Wood)}

Georgia: Athens, two, April 19, 1950; Virginia: Charlottesville, one April 26, 1950; Louisiana: Camp Plauche (near New Orleans), four specimens, January 24, 1944; Nebraska: North Platte, one specimen, June 22, 1950, Omaha, one, June 20, 1950.

\section{GEOPHILUS MORDAX Meinert}

Florida: Kissimmee River, one, March 13, 1950, Archbold Biological Station at Lake Placid, one, March 5, 1950.

GEOPHILUS BECKI Chamberlin, new species

Color of preserved specimens in general orange yellow, the head and antennae darker orange or somewhat chestnut. Legs clear yellow.

Cephalic plate broad, with anterior and caudal ends truncate. Prebasal plate a little exposed at the middle. No definite clypeal foveolae. Median division of labrum large, bearing six stout, strongly sclerotized teeth which are distally blunt or subtruncate (at least in the specimen dissected); lateral pieces with long pectinae. First maxillae each with two long membraneous lappets.

Basal plate broadly trapeziform, wider posteriorly than the head. Claws of prehensors when closed reaching nearly to the end of the first antennal joint; claws with an obscure nodule at base within, the outer joints unarmed. Chitinous lines fine, incomplete.

Dorsal plates deeply bisulcate. 
First spiracle largest, slightly elliptic, the others circular.

Anterior sternites with a shallow mediam depression crossed by a median longitudinal furrows which does not extend upon either anterior or posterior border. Ventral pores not detected.

Tergite of last pedifierous segment broader than long, its caudal margin mesally straight and as long as the anterior.

Last ventral plate also wider than long, narrowing moderately from the middle caudid, but the caudal margin long and nearly straight; lateral margins convex. Coxal pores about a dozen on each side, arranged along and beneath the border of the sternite.

Anal legs of moderate length, bearing claws.

Genital segment subdensely hairy, the hairs short and erect, anal pores present.

Pairs of legs in the female, 61-63.

Length, about $50 \mathrm{~mm}$.

Locality: California, Cabrillo Beach near San Pedro. Three adult females and two young specimens taken August 22, 1950. Specimens found under rocks and kelp at ocean water's edge. Type and paratypes in writer's collection, University of Utah.

This species resembles rather closely G. nicolanus Chamberlin, known only from San Nicolas, Id., but distinct in the presence of anal pores, in having the last tergite caudally truncate instead of strongly convex, in the presence of the nodule or denticle at the base of the claws of the prehensors.

Family Linotaenimde

LINOTAENIA CHIONOPHILA (Wood)

California: Yosemite National Park, two specimens, August 17, 1950.

LINOTAENIA LAEVIPES (Wood)

California: Mill Valley, one, August 10, 1950.

Family Schendylidae

SCHENDYLA NEMORENSIS (Kock)

Utah: Lehi, one female, April 22, 1949.

A species probably introduced from Europe but now widespread in cultivated areas of the United States and Canada, especially in the eastern and central states. 


\section{$2 \mathrm{BHL}$ Biodiversity Heritage Library}

Chamberlin, Ralph V. 1951. "Records of American millipeds and centipeds collected by Dr. D. Elden Beck in 1950." The Great Basin naturalist 11, 27-35. https://doi.org/10.5962/bhl.part.22416.

View This Item Online: $\underline{\text { https://www.biodiversitylibrary.org/item/33385 }}$

DOI: https://doi.org/10.5962/bhl.part.22416

Permalink: https://www.biodiversitylibrary.org/partpdf/22416

\section{Holding Institution}

Harvard University, Museum of Comparative Zoology, Ernst Mayr Library

\section{Sponsored by}

Harvard University, Museum of Comparative Zoology, Ernst Mayr Library

\section{Copyright \& Reuse}

Copyright Status: In copyright. Digitized with the permission of the rights holder.

License: http://creativecommons.org/licenses/by-nc-sa/3.0/

Rights: https://biodiversitylibrary.org/permissions

This document was created from content at the Biodiversity Heritage Library, the world's largest open access digital library for biodiversity literature and archives. Visit BHL at https://www.biodiversitylibrary.org. 